\title{
Pengistimewaan Mafia Pajak
}

Shohibul Anshor Siregar

Apa pun alasannya, sulit untuk tidak melihat sisi buruk rencana tax amnesty (pengampunan pajak) yang kini sedang dibincangkan secara nasional. Itu sangat mengganggu. Sebuah proses legitimasi hukum membentang karpet merah kepada para mafia pajak, menjadikannya pahlawan dan mengistimewakannya di antara warga Negara.

Semua pihak menyadari bahwa pajak merupakan sumber penerimaan yang dominan dalam struktur Anggaran Pendapatan dan Belanja Negara (APBN). Mungkin dalam peluang menduduki porsi berkisar $70 \%$ atau lebih, penerimaan dapat berasal dari sektor pajak. Semua menyadari bahwa pendapatan negara dari tahun ke tahun selalu mengalami peningkatan. Peluang untuk terus ditingkatkan pada masa mendatang sangat terbuka lebar. Tetapi potensi selain masih banyak yang belum digali secara optimal, juga terkendala karena pengelolaan di tangan orang-orang yang kurang berintegritas.

Semua menyadari bahwa untuk menggali penerimaan negara dari sektor perpajakan dibutuhkan upaya-upaya serius. Di sinilah alternatif-alternatif tertentu diajukan semisal tax amnesty, sunset policy dan lain-lain. Jika menonjolkan aspek perhitungan dana yang akan diperoleh saja, tentu orang yang pragmatis akan segera setuju. Hanya saja ia berdampak, terutama atas penegakan hukum serta penataan serius perpajakan kedepan.

Beberapa saran moderat terkait implementasi tax amnesty di Indonesia antara lain bahwa penerapan yang harus dilandasi payung hukum berupa Undang-undang, kejelasan syarat dan tujuannya. Pemberian kebijakan ini semestinya tidak hanya menghapus hak tagih atas wajib pajak (WP) tetapi yang lebih penting lagi adalah memperbaiki kepatuhan WP, sehingga pada jangka panjang dapat meningkatkan penerimaan pajak. Implementasi tax amnesty dapat diterapkan bila syarat-syarat keterbukaan dan akses informasi terhadap masyarakat terpenuhi oleh karena itu apabila tax amnesty akan diterapkan harus menggunakan tax amnesty bersyarat.

Tax amnesty menurut mereka dapat diterapkan terutama pada bidang-bidang atau sektor-sektor industri tertentu saja yang dapat memberikan pengaruh terhadap peningkatan tax ratio dengan syarat terpenuhinya kesiapan sarana dan prasarana pendukung lainnya.

Tetapi jelas, apa pun alasannya, sulit untuk tidak melihat sisi buruk rencana tax amnesty (pengampunan pajak) yang kini sedang dibincangkan secara nasional. Betapa tidak, dalam draft UU versi pemerintah disebutkan bahwa "Pengampunan Nasional adalah penghapusan pajak terutang, penghapusan sanksi administrasi perpajakan, penghapusan sanksi pidana dibidang perpajakan, serta sanksi pidana tertentu dengan membayar uang tebusan, sebagaimana ditetapkan dalam UU ini”. Itu sangat mengganggu. Sebuah proses legitimasi hukum membentang karpet merah kepada para mafia pajak, menjadikannya pahlawan dan mengistimewakannya di antara warga Negara. 
Saya ingin sekali percaya terhadap apa yang dikatakan oleh Menteri Keuangan RI bahwa dana warga negara Indonesia yang selama ini parkir di luar negeri mencapai Rp 4.000 triliun. Meski pun ia tak merinci luar negeri itu Negara mana, agaknya banyak orang tahu Negara yang dimaksud. la juga saya yakini berusaha berbicara jujur ketika berkata "Ekspor SDA Indonesia sudah berlangsung sejak tahun '70-an, sejak zaman migas dulu sampai hari ini. Uang ekspor itu kebanyakan ke mana? Balik ke Indonesia atau tinggal di luar? Tinggal di luar kan? Nah itu yang disimpan di berbagai macam rekening bank di seluruh dunia”.

Namun pertanyaannya ialah, apakah tax Amnesty yang tidak pernah terlepas dari masalah ekonomi bawah tanah (underground economy) atau bahkan hasil kegiatan para pemain berkategori white collar crime ini, yakni bagian dari kegiatan ekonomi yang sengaja disembunyikan untuk menghindari pembayaran pajak, dapat terterima sebagai solusi? Kebijakan ini akan menambah data tentang keengganan pemerintahan Jokowi dalam hal penegakan hukum, terutama kejahatan terhadap keuangan Negara yang umumnya berkategori mega korupsi itu.

Betul bahwa kegiatan ekonomi bawah tanah umumnya berlangsung di semua negara, baik negara maju maupun negara berkembang, dan beberapa Negara pernah tercatat sedikit sukses menerapkan tax amnesty sebagai solusi keuangan yang mengancam. Tetapi jangan lupa, Indonesia pernah berulang kali menerapkannya namun semua usaha itu berakhir tak menggembirakan. Catatan kebijakan kompromi atas kejahatan ini tidak pernah membuahkan hasil yang sesuai harapan. Apa akar masalah sesungguhnya?

Akar Masalah. Manajemen perpajakan di Indonesia kacau. Reformasi birokrasi yang dilakukan bahkan sejak zaman pemerintahan SBY jilid I, meski berbiaya mahal, hasilnya sangat tak memuaskan. Suatu ketika Ponpes Tebuireng, Jombang, melalui sebuah forum yang diselenggarakan Kamis 27 Desember 2012, mengeluarkan sebuah maklumat yang amat menohok pemerintah. Mereka gerah. Mereka kehilangan kepercayaan. Mereka marah.

Bayangkan, forum Halaqah Alim Ulama itu bertajuk "Pajak Negara: Dibayar atau Diingkari?" Alasannya? Uang pajak rakyat selama ini lebih banyak dinikmati segelintir orang, di antaranya untuk mensubsidi bunga obligasi rekap perbankan. Maklumat itu justru dikeluarkan dalam bentuk pernyataan tertulis dan ditandatangani.

Waktu itu Sekjen APPI, Sasmito Hadinagoro menjelaskan soal kesalahan pengelolaan keuangan negara selama ini. Pengelolaan uang pajak rakyat ternyata banyak yang digelontorkan untuk membayar bunga obligasi rekap perbankan. Setiap tahunnya mencapai Rp 60 triliun. Padahal, pembayaran bunga obligasi rekap tersebut, merupakan tanggung jawab para pemilik bank. Itu data lama. Bagaimana data baru yang tanpa perbaikan apa pun dalam sistem perpajakan Indonesia?

Waktu itu Tebuireng mengarahkan tuntutannya kepada Presiden SBY. Gugatan mereka jelas, bahwa jika Presiden SBY tidak berani menghentikan pembayaran obligasi rekap perbankan, maka masyarakat diserukan sebaiknya menunda membayar 
pajak tahun 2013. Hanya karena kebobrokan pengelolaan pajaklah terjadi berbagai masalah besar seperti tunggakan dari berbagai perusahaan, termasuk perusahaan milik Negara. Sebagai bahan perbandingan, berikut catatan data dari tahun 2013.

Pagar Makan Tanaman. Pepatah lama juga berlaku di sini, yakni "pagar makan tanaman" yang melukiskan kadar integritas yang lemah. Bagaimana jika "pagar makan tanaman?" Bagaimana jika "maling teriak maling"? Bagaimana jika karena krisis kepercayaan akhirnya orang tidak lagi ihlas membayar pajak seperti pernah diopinikan secara luas tempohari? Mengapa tunggakan pajak 100 perusahaan (termasuk BUMN) yang mencapai 17 triliun bisa terjadi?

Bandingkanlah misalnya dengan penjelasan Ketua Komite Pengawasan Perpajakan (KPP) Anwar Suprijadi yang mengatakan bahwa setidaknya ada 12 titik rawan penyelewengan keuangan negara yang terdapat pada sektor perpajakan, yakni Direktorat Jenderal Pajak dan Direktorat Jenderal Bea dan Cukai. Dari 12 titik rawan itu 10 titik penting ada di Direktorat Jenderal Bea dan Cukai.

Sebelumnya juga ada pengakuan Dirjen Pajak Mochammad Tjiptardjo, bahwa institusinya memang rawan terhadap penyelewengan. la mengidentifikasi 4 bidang unit kerja yang posisinya selalu bersinggungan dengan kerawanan itu, yakni bidang pemeriksaan, account representative, juru sita, dan penelaah keberatan. Untuk semua bidang itu total aparat yang dipekerjakan mencapai sekitar 15 ribu orang. Katakanlah itu semua data lama. Sudah berubah atau belum?

Tetapi jelas, jika dibayangkan orang sebanyak itu korupsi ramai-ramai melalui sumber pendapatan Negara, seberapa besar kerugian yang diderita? Anehnya, Direktorat Jenderal Pajak (DJP) sendiri mengakui ketidak-memungkinan mengawasi satu per satu secara intens. Ini pengakuan jujur yang menyerah kepada kebobrokan bersifat sistemik dan menahun (kronis).

Penegakan Hukum. Pada segi penegakan hukumnya kita melihat wewenang Mahkamah Agung (MA) yang sulit "menyeberang" menangani pengadilan pajak, kecuali untuk tingkat akhir (PK) ke MA. Pada masa pemerintahan SBY Indonesia memiliki sebuah lembaga penting yang diberinama Satuan Tugas Pemberantasan Mafian Hukum (Satgas). Waktu itu salah seorang anggotanya, Mas Ahmad Santosa, mengekspresikan sesuatu yang mencengangkan bahwa ia baru sadar ternyata MA hanya mengawasi 4 pengadilan (Pengadilan Negeri, Agama, Militer, dan Pengadilan Tata Usaha Negara).

Fakta lain ialah hakim-hakim di pengadilan pajak bukan hakim karir dari MA, tapi pensiunan pegawai pajak sendiri. Oleh karena itulah rentetan kejadian yang terungkap bukan saja mengindikasikan kolusi antar kelembagaan, dan apa yang sudah begitu luas terungkap itu hanyalah sebagian dari cerita permukaan.

Tax amnesty menohok orang-orang baik yang taat bayar pajak. Itu sudah pasti, sembari mengistimewakan para mafia pajak. Para pengemplang pajak yang menjadi sasaran dalam kebijakan ini harusnya dihadapi dengan cara hukum yang elegan. 
Shohibul Anshor Siregar Naskah ini pertamakali oleh Harian Waspada Medan, Senin, 21 Maret 2016, hlm B7 